\title{
Fingerprinting Suspended Sediment Sources in the Nukabira River, Northern Japan
}

\author{
Shigeru MIZUGAKI ${ }^{1}$, Takaaki ABE ${ }^{1}$, Yasuhiro MURAKAMI ${ }^{1}$, Masahiro MARUYAMA ${ }^{1}$ and \\ Mayumi KUBO \\ ${ }^{1}$ Civil Engineering Research Institute for Cold Region, Public Works Research Institute \\ (Hiragishi 1-3-1-34, Toyohira-ku, Sapporo, Hokkaido 0628602, Japan) \\ E-mail: gakimizujp@yahoo.co.jp (Shigeru MIZUGAKI)
}

\begin{abstract}
Geological setting is crucial to the occurrence of slope failure and landslides, resulting in prolonged suspended sediment runoff; in this sense, local geology can affect the magnitude of suspended sediment yield. To clarify the suspended sediment sources in a watershed with various geological units, hydrological monitoring and fingerprinting techniques using natural radionuclides were conducted during a heavy rainfall event in August 2010 in the Nukabira River watershed, a tributary of the Saru River, in northern Japan. A GIS analysis for slope failure and landslide areas was also conducted to investigate the distribution of potential suspended sediment sources. During the rainfall event, the dominant sources of suspended sediment were found to be areas consisting of metamorphic rock (31\%), sedimentary rock (30\%), and accretionary sedimentary rock (24\%). The highest sediment yield was found in metamorphic rock, which is consistent with the dense distribution of slope failure and landslides identified by the GIS analysis. Active landslides can introduce a significant amount of sediment from the hillslope to the stream channel, providing a source of fine sediment. In the area of the accretionary basalt block, there was an inconsistency between the sediment yield and the density of slope failure and landslides, perhaps attributable to the lack of a fine particle fraction in the sediment deposited on the bare slope along the stream channel and riverbed due to the resistance of bed rock to slaking and weathering. These results indicate that natural radionuclides can be used in order to elucidate the suspended sediment sources and sediment yield of various geological units within a watershed.
\end{abstract}

Key words: fingerprinting, suspended sediment, natural radionuclide, geology, GIS

\section{INTRODUCTION}

Mass wasting like landslides, gullying, debris flow, and riparian bank erosion, triggered by episodic storm events, often generates a large amount of sediment, frequently resulting in on-site sediment disasters in residential and agricultural areas. Although some of the sediment produced by mass wasting is carried from the hillslopes to the river channel, a fair percentage of the sediment is usually deposited on the hillslopes, foot slopes, and riverbeds and is transported downstream in subsequent rainfall events. This leads to a prolonged discharge of suspended sediment [Page et al., 1999; Koi et al., 2008]. At the outlet of the catchment, most of the sediment is transported as suspended sediment, the importance of which is recognized in the transport of nutrients and contaminants such as phosphorus (P), pesticides, polychlorinated biphenyls (PCBs), heavy metals, and pathogens through fluvial systems [Walling, 2005]. Therefore, while erosion control is primarily concerned with controlling on-site sediment disasters in mountainous regions, sediment control programs are more concerned with downstream problems and must consider a wider range of potential sources [Walling, 2005].

The suspended sediment load transported by a river or stream will commonly contain a mixture of sediments delivered from different locations and from different source types within the contributing catchment [Collins et al., 1998; Yieger et al., 2002; Mizugaki et al., 2008]. In the case of a catchment that has experienced extensive landslides and gullying, mass wasting scarring could represent the 
primary source [Page et al., 1999; Koi et al., 2008]. Since the occurrence of mass movement such as landslides, slope failure, and gullying is well known to depend on the underlying geology [Aipassa et al., 1990; Dai and Lee, 2002; Murakami et al., 2006], numerous researchers have reported that the differences in the amount of sediment at the outlet of the catchment (i.e., deposited sediment in dam reservoirs) depend on the dominant underlying geology in the catchment [Tanaka and Ishigai, 1951; Ezaki, 1966; Marutani et al., 2000; Mizutani, 2004; Okano et al., 2004; Hasegawa et al., 2005]. These literatures are based on comparisons of sediment yield among catchments, by assuming a uniform geology in each catchment; however, these studies have not dealt with the spatial variation in sediment sources within a catchment.

Recently, sediment fingerprinting studies have been focused on elucidating the suspended sediment sources within a catchment, using the quantitative interpretation of multivariate properties and property ratios, encompassing various mineralogic [Ohishi et al., 2010], magnetic [Foster and Lees, 1999], radiometric [Olley et al., 1993; Collins et al., 1998; Walling et al., 1999; Yeager et al., 2002; Kato et al., 2005; Mizugaki et al., 2008; Uchida et al., 2009; Fukuyama et al., 2010], and chemical [Ishida et al., 2010] parameters. The level of radiation on the earth's surface has been reported to differ depending on the underlying bed rock [Wollenberg and Smith, 1990; Furukawa, 1993; Matsuda and Minato, 1999]; therefore, researchers have used the activities of radionuclides as parameters by which to fingerprint the suspended sediment sources in a multivariate sediment mixing model [Collins et al., 1998; Walling et al., 1999; Yeager et al., 2002].

The identification of suspended sediment sources is a key precursor to the design of effective sediment management and control strategies [Walling, 2005]. Recent advances in geographic information systems (GIS) and databases aid in the identification of scars of landslides and slope failure as primary sources of suspended sediment [Murakami et al., 2006] and topographic features as potential controlling factors of suspended sediment yield [Okano et al., 2004; Hasegawa et al., 2005; Murakami et al., 2006]. In addition, the suspended sediment sources causing prolonged sediment runoff can be identified by a fingerprinting technique. The objectives of this study are to examine this fingerprinting technique using radionuclides and to elucidate the suspended sediment sources in a catchment that has undergone landslides and slope failure. To achieve these objectives, a field survey and fingerprinting were conducted in the Saru River and $\mathrm{Mu}$ River watersheds, in northern Japan, where a heavy storm event in August 2003 caused extensive landslides and slope failures.

\section{MATERIAL AND METHODS}

\subsection{Study site}

The study site encompassed two adjacent watersheds - the Saru River and $\mathrm{Mu}$ River watersheds-draining from the Hidaka mountain range in central Hokkaido, northern Japan, to the Pacific Ocean (Fig. 1). At the river mouth, the catchment areas of the Mu River and Saru River are $1,270 \mathrm{~km}^{2}$ and $1,350 \mathrm{~km}^{2}$, respectively. In the Saru River watershed, annual precipitation ranges from $975 \mathrm{~mm}$ in downstream areas (Hidaka-Monbetsu) to $1,353 \mathrm{~mm}$ in upstream areas (Hidaka). Eighty-five percent of both watersheds is covered by forest; agricultural land (5.5\%) and residential areas (9.4\%) lie along the river channel in the downstream area. The dominant geology of the study area consists of plutonic rock in the upstream area, cretaceous sedimentary rock and an accretionary complex from the upstream to midstream areas, and neocene sedimentary rock in the downstream area. Basalt block in the accretionary complex and metamorphic rock consisting of sedimentary rock and serpentinite are found in the midstream area.

From August 8-9, 2003, an extreme storm event in the form of typhoon 1003 (Etau) resulted in the highest discharge and sediment yield seen in the previous several decades, especially in the Saru River watershed. In the Nukabira River watershed, which is the subwatershed of the Saru River, the total rainfall during the event was over $400 \mathrm{~mm}$, and the maximum rainfall intensity observed by radar was over $80 \mathrm{~mm} \mathrm{~h}^{-1}$, resulting in approximately

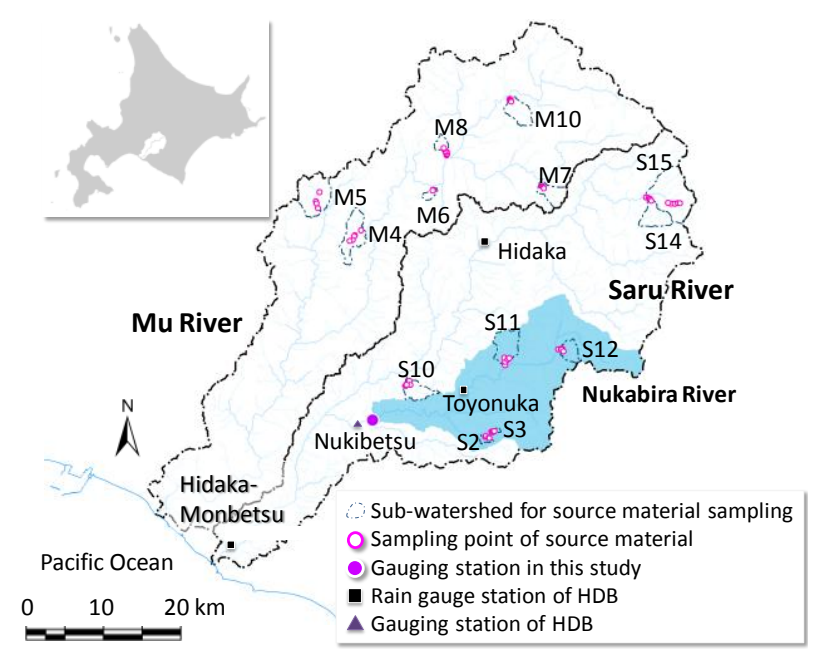

Fig.1 Location of study site. Blue area denotes the Nukabira River watershed, where is the study site for fingerprinting suspended sediment sources. 
4,000 slope failures and landslides [Murakami and Nakatsugawa, 2004]. Suspended sediment load during the event was estimated to be $1,267,000 \mathrm{t}$ at the Nukibetsu gauging station of the Hokkaido Development Bureau (HDB), for which the watershed area is $384 \mathrm{~km}^{2}$, including the Nukibetsu River watershed [Murakami and Nakatsugawa, 2004]. This amount was equivalent to only $8.9 \%$ of the sediment deposited on the hillslope by landslides and slope failure during the event [Murakami and Watanabe, 2007]. The residue, left at the foot slope and river bed across the watershed, may have been transported by subsequent storm events.

\subsection{Field sampling and observation}

Detailed source material sampling was undertaken within each of the major geological systems constituting the study basin in order to examine the provenance of bulk suspended sediment samples collected at the basin outlet in terms of geological subareas. First, for sampling potential source materials, 13 sub-catchments were selected to encompass the major geological categories constituting the study area based on the geological map [Geological Survey of Japan, AIST, 2009] (Fig. 1). The geology of each sub-catchment is shown in Table 1. Second, in each sub-catchment, 5-8 bare slopes adjacent to the stream channel were selected as sampling points, from which 5 samples were collected from top soil likely to be eroded (i.e., 0-5 $\mathrm{cm}$ depth) and combined into a single sample. A total of 72 samples were obtained for the study area.

To observe the discharge and sediment runoff in the Nukabira River watershed, a water level gauge (OYO, S\&DL mini; Tokyo, Japan) and turbidity meter (JFE Advantec, Infinity Turbi; Nishinomiya, Japan) were installed at the Nukibetsu Bridge, situated at the downstream end of the Nukabira River. The water level and turbidity were continuously recorded at $10-\mathrm{min}$ intervals. The discharge and suspended sediment concentration were calculated by regression functions between water level and discharge and between turbidity and suspended sediment concentration, respectively [Abe et al., in this issue]. Suspended sediment discharge during the observation period was calculated using the following equation:

$$
L=\sum_{i=1}^{n} C_{(\mathrm{t})} Q_{(\mathrm{t})} d t
$$

where $L$ is the total discharge of suspended sediment during the event (ton), $C_{(\mathrm{t})}$ is the suspended sediment concentration at time $t(\mathrm{mg} / \mathrm{L})$, and $Q_{(\mathrm{t})}$ is the runoff discharge at time $t\left(\mathrm{~m}^{3} / \mathrm{s}\right)$.

To collect the suspended sediment during the storm event, a time-integrated suspended sediment sampler [Phillips et al., 2000] was installed at Nukibetsu Bridge (Fig. 1). The suspended sediment accumulated in the sampler from August 11 to September 1, 2010, was collected in order to fingerprint the suspended sediment source. Surface water was also collected from the stream channel at Nukibetsu Bridge at the highest water level during the event.

\subsection{Sample processing and analysis}

Gamma-ray spectrometry was conducted in order to fingerprint the suspended sediment source. The collected soil and suspended sediment samples were dried for over $48 \mathrm{~h}$ at $105^{\circ} \mathrm{C}$, sieved using a $0.5-\mathrm{mm}$ open sieve, and packed in a 5-ml polyethylene bottle (Kartell, 737; Milano, Italy). These samples were sealed for more than five times the half-life of ${ }^{222} \mathrm{Rn}$, that is, $21 \mathrm{~d}$, before the analysis began, in order to allow equilibrium to develop between ${ }^{226} \mathrm{Ra}$ and ${ }^{222} \mathrm{Rn}$ [Joshi, 1987; Murray et al., 1987]. High-resolution gamma-ray spectrometry was employed to resolve 13 radionuclides, i.e., ${ }^{210} \mathrm{~Pb}$ (46.5 keV), ${ }^{234} \mathrm{Th}(63.3 \mathrm{keV}),{ }^{231} \mathrm{Th}(84.2 \mathrm{keV})$, ${ }^{226} \mathrm{Ra}(186 \mathrm{keV}),{ }^{212} \mathrm{~Pb}(238 \mathrm{keV}),{ }^{214} \mathrm{~Pb}(352 \mathrm{keV})$, ${ }^{208} \mathrm{Tl}(583 \mathrm{keV}),{ }^{214} \mathrm{Bi}(609 \mathrm{keV}),{ }^{137} \mathrm{Cs}(662 \mathrm{keV})$, ${ }^{212} \mathrm{Bi}(727 \mathrm{keV}),{ }^{228} \mathrm{Ac}(911 \mathrm{keV}),{ }^{40} \mathrm{~K}(1461 \mathrm{keV})$, and lead-210 excess $\left({ }^{210} \mathrm{~Pb}_{\mathrm{ex}}\right)$ as the difference between the photo peaks of ${ }^{210} \mathrm{~Pb}$ and ${ }^{214} \mathrm{~Pb}[$ Joshi, 1987; Murray et al., 1987], by using a well-type HPGe gamma detector (ORTEC GWL-120-15; Oak Ridge, U.S.A.) coupled with a multichannel analyzer (SEIKO EG\&G MCA7600; Tokyo, Japan) at our laboratory in the Civil Engineering Research Institute for Cold Region, PWRI. The energy and efficiency calibrations for this detector were performed using a standard sample including 11 radionuclides (Eckert \& Ziegler; MODEL7603): ${ }^{210} \mathrm{~Pb}(46.5 \mathrm{keV}),{ }^{241} \mathrm{Am}(59.5 \mathrm{keV}),{ }^{109} \mathrm{Cd}(88.0$ $\mathrm{keV}),{ }^{57} \mathrm{Co}(122 \mathrm{keV}),{ }^{139} \mathrm{Ce}(166 \mathrm{keV}),{ }^{203} \mathrm{Hg}(279$ $\mathrm{keV}),{ }^{113} \mathrm{Sn}(392 \mathrm{keV}),{ }^{85} \mathrm{Sr}(514 \mathrm{keV}),{ }^{137} \mathrm{Cs}(662$ $\mathrm{keV}),{ }^{60} \mathrm{Co}(1173 \mathrm{keV}, 1333 \mathrm{keV})$, and ${ }^{88} \mathrm{Y}(898 \mathrm{keV}$, $1836 \mathrm{keV})$. For the analysis of radionuclide activity, each sample was measured for over 28,800 s. All the detected radionuclides were quantified according to the activity $\left(\mathrm{Bq} \mathrm{g}^{-1}\right)$ from the reference samples.

The particle size distribution was measured for all the potential source materials and suspended sediment by means of sieving and laser beam diffraction. Sieving was conducted for coarser fractions over $0.075 \mathrm{~mm}$ in diameter, and laser beam diffraction (Shimadzu SALD-3000S and SALD-2000J; Shimadzu Corp., Kyoto, Japan) was used for finer fractions less than $0.5 \mathrm{~mm}$ in diameter after hydrogen peroxide pretreatment. 
Table 1 Geological unit of sub-catchment for sampling potential source materials

\begin{tabular}{|c|c|c|c|c|}
\hline $\begin{array}{l}\text { Sub- } \\
\text { catchment }\end{array}$ & Era & Period & Bed rock & Geology \\
\hline M4 & Unknown & Unknown & Metamorphic & Ultramafic \\
\hline M5 & Methozoic & Late Cretaceous & Sedimentary & Marine sedimentary rock \\
\hline M6 & Methozoic & Jurassic-Early Cretaceous & Metamorphic & Kamuikotan metamorphic rock \\
\hline $\mathrm{M7}$ & Methozoic & $\begin{array}{l}\text { Late Jurassic-Early } \\
\text { Cretaceous }\end{array}$ & Accr. Volcanic & Mafic volcanic rock \\
\hline M8 & Methozoic & Jurassic-Early Cretaceous & Metamorphic & Kamuikotan metamorphic rock \\
\hline M10 & Methozoic & Early-Late Cretaceous & $\begin{array}{l}\text { Accretionary complex } \\
\text { (Sedimentary) }\end{array}$ & Mainly sedimentary rock \\
\hline S2 & Methozoic & Late Cretaceous & Sedimentary & Marine sedimentary rock \\
\hline S3 & Pale-Methozoic & Permian-Late Jurassic & Accr. Basalt & Exotic basalt block \\
\hline S10 & Cenozoic & Eocene-Oligocene & Sedimentary & Marine or non-marine sedimentary rock \\
\hline S11 & Methozoic & $\begin{array}{l}\text { Late Jurassic-Early } \\
\text { Cretaceous }\end{array}$ & $\begin{array}{l}\text { Accretionary complex } \\
\text { (Sedimentary) }\end{array}$ & Mainly sedimentary rock \\
\hline S12 & Methozoic & Late Cretaceous & Sedimentary & Marine sedimentary rock \\
\hline S14 & Cenozoic & Early-Middle Eocene & Plutonic & Mafic plutonic rock \\
\hline S15 & Cenozoic & Early Miocene & Plutonic & Felsic plutonic rock \\
\hline
\end{tabular}

\subsection{Statistical and numerical methods}

The geology of the sampling points for the source material was determined and categorized into source groups on the basis of three geological categories: era, bedrock, and rock type. A two-stage statistical procedure was used to identify optimum sets of source material and sediment properties for use as composite fingerprints [cf. Collins et al., 1997, 1998; Walling et al., 1999]. First, the Kruskal-Wallis H-test was used to establish which properties exhibited significant differences between individual source groups within a particular category of sources. Second, multivariate discriminant function analysis was applied to the properties selected in the first stage in order to identify the set of properties, or composite fingerprint, that afforded optimum discrimination between source groups. A stepwise selection algorithm based on the minimization of Wilks' lambda or $U$-statistic was used in this analysis. These statistical analyses were performed using the JMP 7 software (SAS institute Inc., USA, 2007).

If most of the suspended sediment originates from a particular source group, the tracer properties associated with that sediment will be similar to those associated with that source group. Since the similarity (definable as the inverse of the difference) in tracer properties between suspended sediment and source area can represent the contribution of the source area to the suspended sediment [Ishida et al., 2010], we assumed that the contribution of a source group to the suspended sediment can be calculated as follows:

$$
p_{i}=\frac{\frac{1}{d_{i}}}{\sum_{i=1}^{n} \frac{1}{d_{i}}}, \quad \sum_{i=1}^{n} p_{i}=1
$$

where $p_{i}$ is the contribution of source group $i$ to the suspended sediment, and $d_{i}$ is the difference in tracer properties between source group $i$ and the suspended sediment. In this study, the Mahalanobis distance in tracer properties between source groups and suspended sediment was employed because it accounts for the deviation in tracer properties associated with source materials from each source group in $d_{i}$.

\subsection{GIS Analysis}

To examine the validity of the estimated contribution of source areas to suspended sediment, GIS was used to investigate the topographic features and precipitation for each source area as indices of potential sediment yield (ESRI; ArcGIS 9.3.1, Spatial Analyst). Altitude and slope gradient were evaluated on the basis of a 10-m mesh digital elevation model (DEM) provided by the Geospatial Information Authority of Japan. For relief and profile curvature, the original DEM was re-sampled to a mesh size of $150 \mathrm{~m}$ and $30 \mathrm{~m}$, respectively, to represent the indices of suspended sediment yield and transport [Nishida et al., 1997]. The locations of slope failure and landslide scars caused by the extreme event in 2003 were also investigated for each source area. GIS databases of slope failure and landslides were employed from Murakami and Nakatsugawa [2004] and Yamagishi [1993], respectively. Precipitation during the event was investigated using precipitation in 5-min intervals in a mesh size of $1 \mathrm{~km}$, observed by a weather radar 


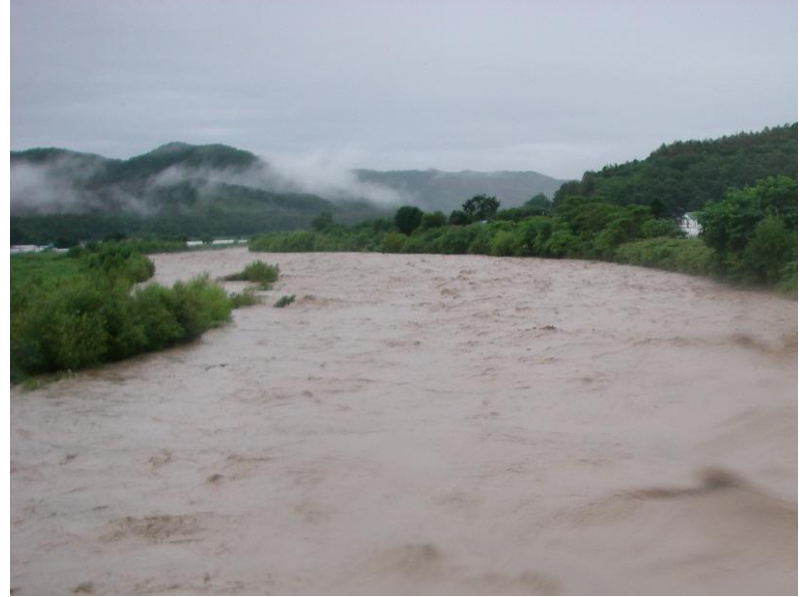

Fig.2 Turbid water during the rainfall event on August 12, 2010, at the Nukibetsu Bridge of Nukabira River

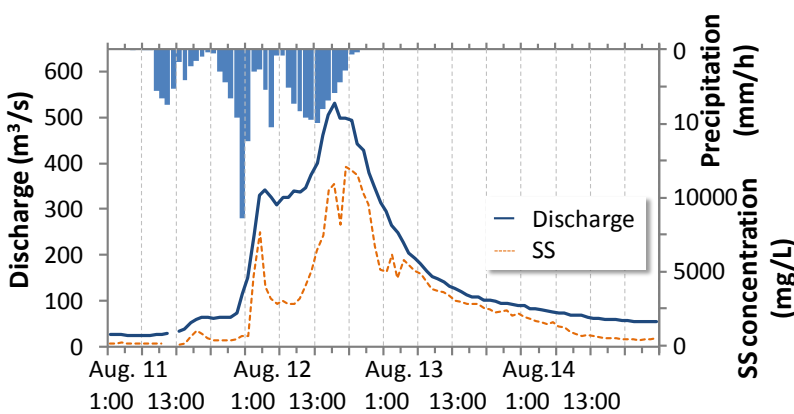

Fig.3 Precipitation, discharge and suspended sediment concentration during the event

belonging to the Japan Meteorological Agency. The total precipitation and maximum rainfall intensity for $1 \mathrm{~h}$ during the event were calculated for each source area.

\section{RESULTS}

\subsection{Suspended sediment load}

In the Nukabira River watershed, the rainfall event from August 11-12, 2010, resulted in precipitation of $199.6 \mathrm{~mm}$ in total and $22.7 \mathrm{~mm} / \mathrm{h}$ in maximum intensity, as recorded by the weather radar. This resulted in a middle magnitude storm runoff event (Fig. 2). Runoff discharge at the outlet of the Nukabira River showed a quick response to rainfall, and discharge peaks were found $3 \mathrm{~h}$ after the rainfall peak (Fig. 3). Suspended sediment concentration had already reached over $1,000 \mathrm{mg} / \mathrm{l}$ with the first increase in discharge and was over $12,000 \mathrm{mg} / \mathrm{l}$ at its maximum value $2 \mathrm{~h}$ after the maximum discharge. Suspended sediment load and suspended sediment yield during this event were $293,377 \mathrm{t}$ and $1,010 \mathrm{t} / \mathrm{km}^{2}$, respectively.

Suspended sediment concentration in the recession stage of discharge was higher than that in the rising stage, suggesting a counter-clockwise hysteresis for discharge [Abe et al., in this issue].
Further, a significant amount of suspended sediment was recorded during the recession stage [Williams, 1989]. The suspended sediment load and suspended sediment yield observed in this study were equivalent to $23 \%$ and $30.6 \%$, respectively, of those observed downstream at the Nukibetsu gauging station of the HDB (Fig. 1) during the extreme event in August 2003 [Murakami and Nakatsugawa, 2004].

\subsection{Appropriate combination of tracer properties and source areas of suspended sediment}

The non-parametric Kruskal-Wallis H-test was performed for 13 radionuclides associated with source material samples, and a significant difference between source groups was found for 8-9 radionuclides (Table 2). For those radionuclides showing significant differences between source groups, multivariate discriminant analysis was

Table 2 The results of using the Kruskal-Wallis test to assess the ability of each tracer property to discriminate between surface (c. top $5 \mathrm{~cm}$ ) soil from various source groups categorized by geological units such as period, geological types and bed rock.

\begin{tabular}{|c|c|c|c|c|c|c|}
\hline \multirow{2}{*}{$\begin{array}{c}\text { Tracer } \\
\text { property }\end{array}$} & \multicolumn{2}{|c|}{ Period (8) } & \multicolumn{2}{|c|}{ Geology (10) } & \multicolumn{2}{|c|}{ Bed rock (6) } \\
\hline & $H$ value & $P$ value & $H$ value & $P$ value & $H$ value & $P$ value \\
\hline $\mathrm{Pb}-210$ & 18.26 & $0.011 *$ & 23.44 & $0.005 *$ & 11.46 & $0.043^{*}$ \\
\hline Th-234 & 11.16 & 0.132 & 16.53 & 0.057 & 13.83 & $0.017^{*}$ \\
\hline Th-231 & 7.52 & 0.377 & 12.87 & 0.169 & 7.96 & 0.159 \\
\hline Ra-226 & 12.35 & 0.090 & 13.74 & 0.132 & 9.27 & 0.099 \\
\hline $\mathrm{Pb}-212$ & 41.33 & $0.000 *$ & 46.98 & $0.000 *$ & 43.49 & $0.000 *$ \\
\hline $\mathrm{Pb}-214$ & 22.65 & $0.002 *$ & 33.35 & $0.000 *$ & 29.46 & $0.000 *$ \\
\hline TI-208 & 31.05 & $0.000 *$ & 38.47 & $0.000 *$ & 32.79 & $0.000 *$ \\
\hline $\mathrm{Bi}-214$ & 12.22 & 0.094 & 17.29 & $0.044 *$ & 13.41 & 0.020 * \\
\hline Cs-137 & 9.59 & 0.213 & 11.57 & 0.239 & 10.21 & 0.070 \\
\hline $\mathrm{Bi}-212$ & 17.97 & $0.012 *$ & 15.64 & 0.075 & 13.63 & 0.018 * \\
\hline Ac- 228 & 36.64 & $0.000 *$ & 42.23 & $0.000 *$ & 39.67 & $0.000 *$ \\
\hline $\mathrm{K}-40$ & 23.83 & $0.001 *$ & 41.49 & $0.000 *$ & 39.57 & $0.000 *$ \\
\hline Pbex & 21.05 & $0.004 *$ & 24.33 & $0.004 *$ & 9.23 & 0.100 \\
\hline
\end{tabular}

Table 3 The results of using stepwise discriminant function analysis to identify which combination of tracer properties provides the best composite fingerprint for differentiating source materials on the basis of geology groups

\begin{tabular}{|c|c|c|c|c|c|}
\hline \multicolumn{2}{|l|}{ Period (8) } & \multicolumn{2}{|l|}{ Geology (10) } & \multicolumn{2}{|l|}{ Rock $(6)^{*}$} \\
\hline $\begin{array}{l}\text { Tracer } \\
\text { property }\end{array}$ & $\begin{array}{l}\text { Cum. \% } \\
\text { classified } \\
\text { correctly }\end{array}$ & $\begin{array}{l}\text { Tracer } \\
\text { property }\end{array}$ & $\begin{array}{r}\text { Cum. \% } \\
\text { classified } \\
\text { correctly }\end{array}$ & $\begin{array}{l}\text { Tracer } \\
\text { property }\end{array}$ & $\begin{array}{r}\text { Cum. \% } \\
\text { classified } \\
\text { correctly }\end{array}$ \\
\hline $\mathrm{Pb}-212$ & 33.33 & $\mathrm{~Pb}-212$ & 33.33 & $\mathrm{~Pb}-212$ & 50.00 \\
\hline $\mathrm{K}-40$ & 36.11 & $\mathrm{~K}-40$ & 40.28 & $\mathrm{~K}-40$ & 66.67 \\
\hline $\mathrm{Bi}-212$ & 44.44 & Ac-228 & 40.28 & Ac-228 & 72.22 \\
\hline Ac-228 & 43.06 & Pbex & 45.83 & & \\
\hline Pbex & 43.06 & TI-208 & 51.39 & & \\
\hline TI-208 & 56.94 & $\mathrm{Bi}-214$ & 55.56 & & \\
\hline \multirow[t]{2}{*}{$\mathrm{Pb}-214$} & 61.11 & $\mathrm{~Pb}-214$ & 58.33 & & \\
\hline & & $\mathrm{Pb}-210$ & 61.11 & & \\
\hline
\end{tabular}


performed in each geological category to seek the best combination of radionuclides. The discriminant analysis showed that the highest number of correct classifications, $72.22 \%$, was found when a combination of three radionuclides $-{ }^{212} \mathrm{~Pb},{ }^{40} \mathrm{~K}$, and ${ }^{228} \mathrm{Ac}$ - was selected to discriminate the following 6 source groups by bed rock: sedimentary rock, accretionary sedimentary rock, accretionary basalt block, accretionary volcanic rock, plutonic rock, and metamorphic rock (Table 3). A geological map

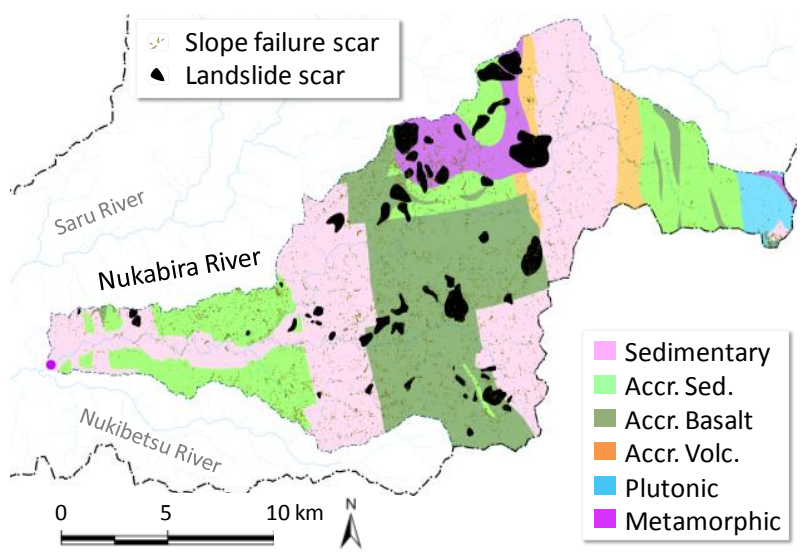

Fig.4 Bed rock and scar of slope failure (Murakami and Nakatsugawa, 2004) and landslide (Yamagishi, 1993) in the Nukabira River watershed.

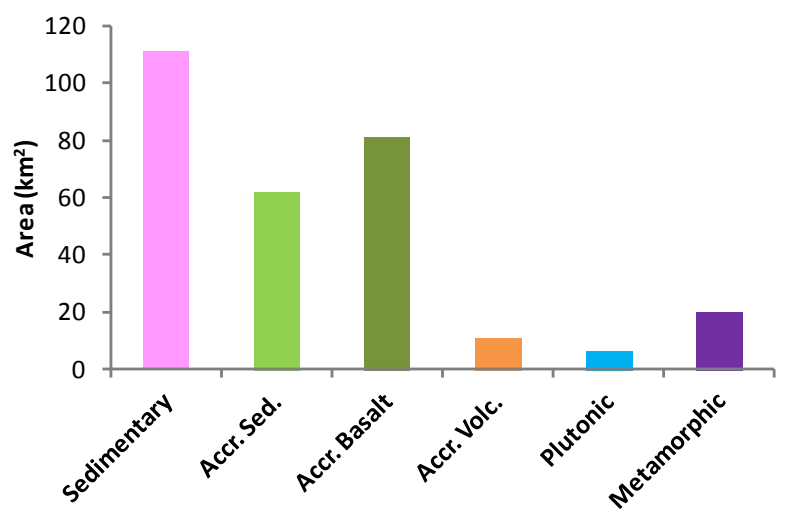

Fig.5 Bed rock composition in the Nukabira River watershed

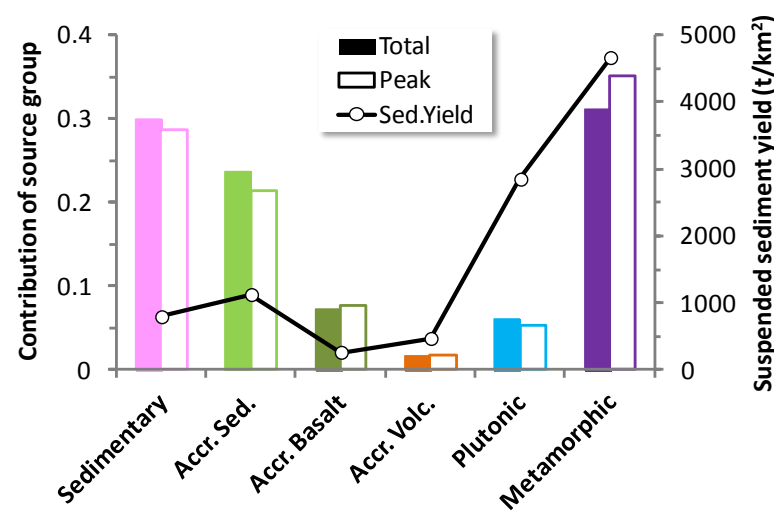

Fig.6 Contribution to suspended sediment and sediment yield from various bed rock areas shows that all six source groups of bed rock are found in the Nukabira River watershed (Fig. 4). Sedimentary rock covers the largest area and, together with accretionary basalt block and accretionary sedimentary rock, accounts for $87.5 \%$ of the entire area of the watershed (Fig. 5).

Using ${ }^{212} \mathrm{~Pb},{ }^{40} \mathrm{~K}$, and ${ }^{228} \mathrm{Ac}$ as appropriate tracers, the contribution of source groups on the basis of bed rock to suspended sediment collected at peak discharge and during the event were calculated by equation 1 . Little difference in the contribution of source groups to suspended sediment was found between the sediment samples collected at peak discharge and during the event (Fig. 6). For sediment during the event, the highest contributions were found for metamorphic rock at $31.2 \%$ and sedimentary rock at $30.0 \%$, followed by accretionary sedimentary rock at $23.7 \%$, resulting in over $80 \%$ of the suspended sediment originating from these three bed rocks. The contributions of accretionary basalt block, plutonic rock, and accretionary volcanic rock were significantly low, with contributions of $7.7 \%, 5.4 \%$, and $1.7 \%$, respectively.

However, a different tendency was found in suspended sediment yield for each bed rock, which was calculated by products of suspended sediment yield during the event and the contribution of each bed rock (Fig. 6). Significantly high sediment yield was found from metamorphic rock $\left(4,662 \mathrm{t} / \mathrm{km}^{2}\right)$, followed by plutonic rock $\left(2,847 \mathrm{t} / \mathrm{km}^{2}\right)$, showing significantly higher yields compared to those from sedimentary rock $\left(794 \mathrm{t} / \mathrm{km}^{2}\right)$, accretionary sedimentary rock $\left(1,125 \mathrm{t} / \mathrm{km}^{2}\right)$, and accretionary basalt block $\left(263 \mathrm{t} / \mathrm{km}^{2}\right)$, in spite of their large area in the watershed. The sediment yield found from accretionary basalt was the lowest, despite the fact that it accounted for the second largest area in the watershed.

\subsection{Spatial distribution of controlling factors in suspended sediment yield and transport}

Topographic features such as altitude, slope gradient, relief, and profile curvature were investigated for each source group area in order to

Table 4 Topographic features of the Nukabira River watershed

\begin{tabular}{llrrrrrr}
\hline & & Sed. & \multicolumn{2}{c}{ Accretionary } & & Plut. & Meta. \\
& & & Sed. & Basalt & Volc. & & \\
\hline Area & $\mathrm{km}^{2}$ & 111.0 & 61.9 & 81.4 & 10.7 & 6.2 & 19.6 \\
Altitude & $\mathrm{m}$ & 447.1 & 613.6 & 630.1 & 788.6 & 1436.6 & 846.3 \\
Slope & Deg. & 22.8 & 27.7 & 30.9 & 35.9 & 33.6 & 21.7 \\
$\begin{array}{l}\text { Relief } \quad \mathrm{m} \\
\text { Prof. }\end{array}$ & 98.6 & 125.2 & 156.4 & 181.5 & 203.8 & 110.8 \\
curvature & 0.036 & 0.019 & 0.021 & 0.035 & 0.017 & 0.003 \\
\hline
\end{tabular}



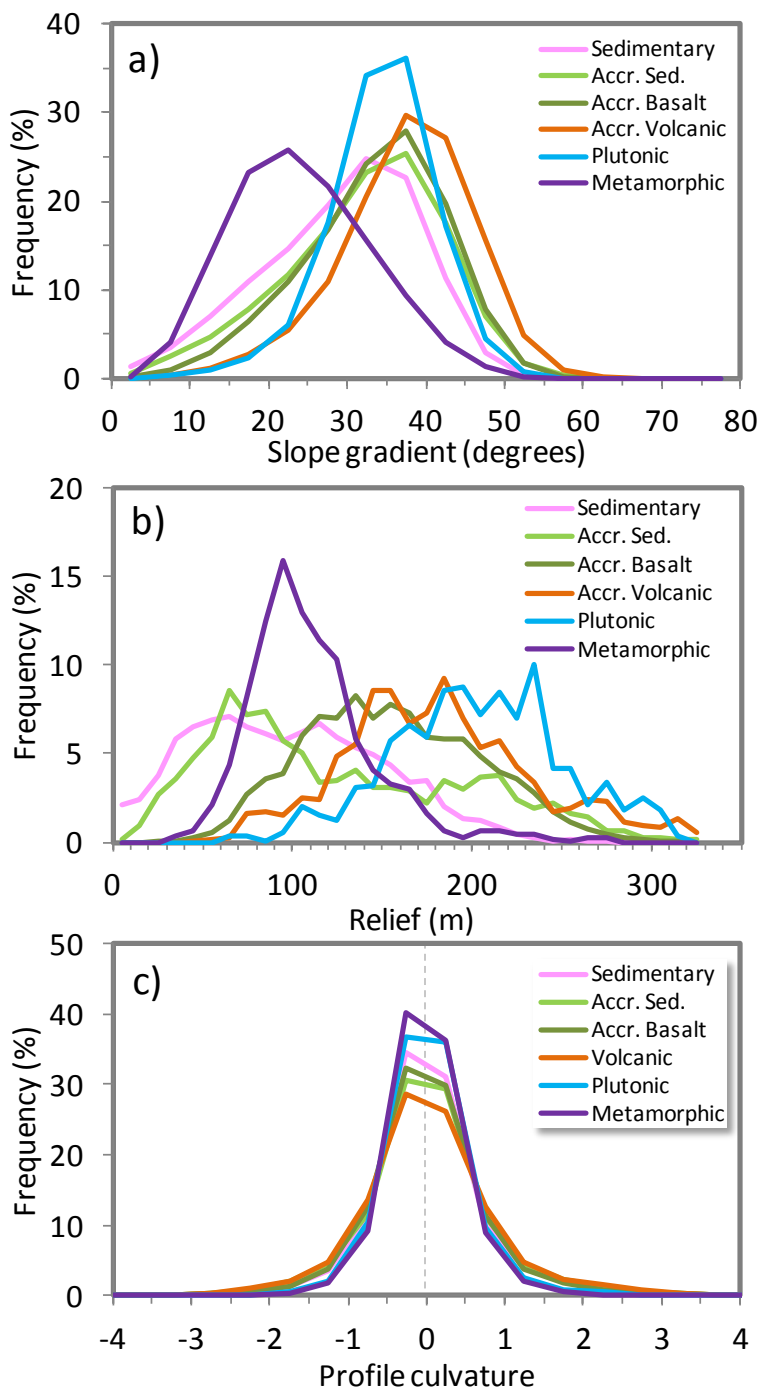

Fig.7 Topographic features of bed rock categories in the Nukabira River watershed. a) Slope gradient, b) relief, and c) profile curvature.

compare the potential controlling factors of suspended sediment yield and transport among the source groups (Table 4). In the volcanic rock, the slope gradient was slightly steeper than those in the other source groups, while the metamorphic rock had predominantly gentler slopes of less than 25 degrees. The relief in all source groups ranged widely, but the metamorphic rock was represented by a predominant relief of 90 to $100 \mathrm{~m}$ (Fig. 7b). The plutonic rock showed the highest relief because it had the highest altitude, followed by the accretionary volcanic rock and accretionary basalt block (Fig. 7b, Table 4). In the sedimentary rock and accretionary sedimentary rock, the predominant relief was 70 to $80 \mathrm{~m}$ due to the lower altitude. Profile curvature was similar among the source groups and showed predominantly negative values (Fig. 7c); however, the average profile curvature showed positive values (Table 4). This result
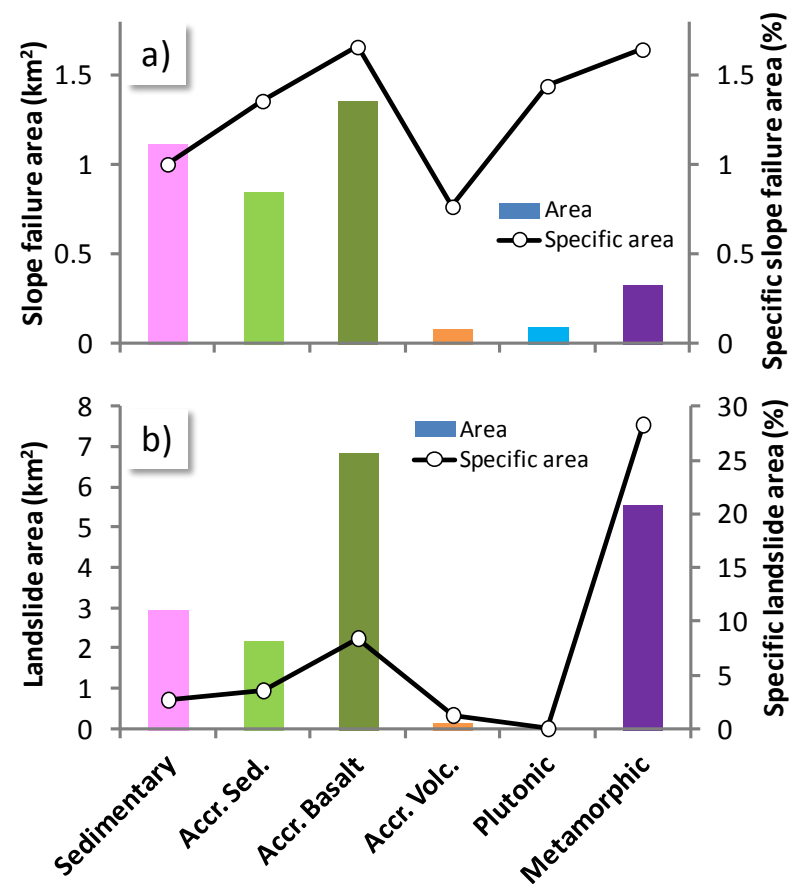

Fig.8 Areas of a) slope failure and b) landslide in the Nukabira River watershed

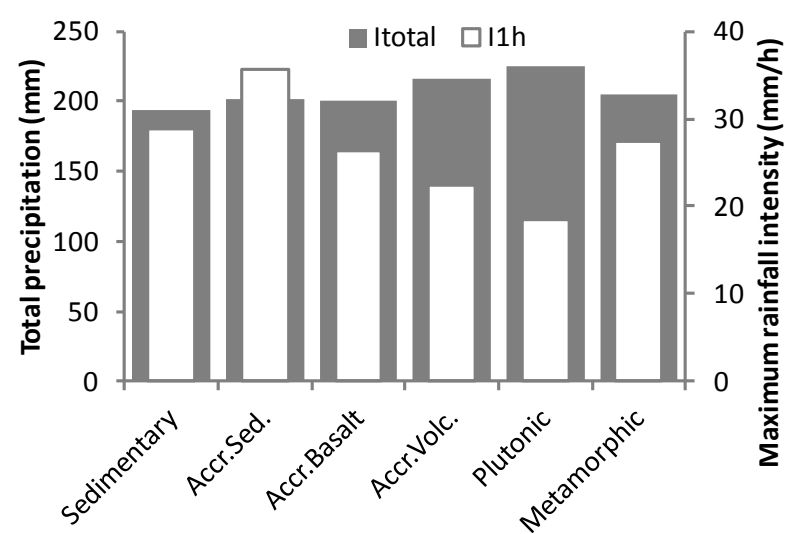

Fig.9 Total precipitation and maximum rainfall intensity in various bed rock areas of the Nukabira River watershed

suggests that convex slopes are slightly dominant in all source areas.

The area of slope failure was highest in the accretionary basalt block, with a maximum density of $1.66 \%$, attributed to the large amount of rainfall and its high intensity during the extreme event in 2003 [Murakami and Nakatsugawa, 2004] (Fig. 8a). In the sedimentary and accretionary sedimentary rocks, the area of slope failure was high because these types of rocks accounted for a larger area of the watershed; however, the density of slope failure was somewhat low in the sedimentary rock. With regard to the metamorphic and plutonic rocks, the density of slope failure was as high as $1.65 \%$ and $1.44 \%$, respectively, despite the small area of slope failure. A large area of landslide scar was found in the metamorphic rock and accretionary basalt block, 


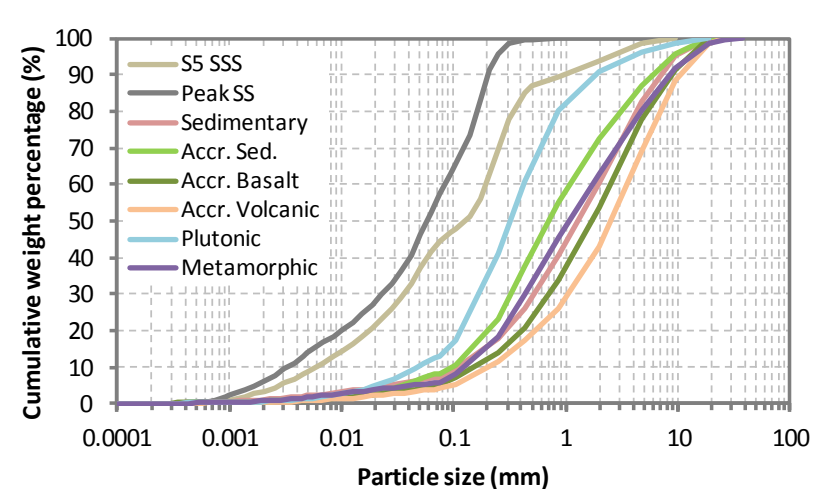

Fig.10 Particle size distribution of potential source materials in each bed rock areas.

with an especially high density in the metamorphic rock at $28.6 \%$ (Fig. $\mathbf{8 b}$ ). The density of landslide scars was lower in the sedimentary rock and accretionary sedimentary rock, and there were few landslides in the accretionary volcanic rock.

Precipitation during the event was very similar among the source groups, ranging from $193.8 \mathrm{~mm}$ to $224.8 \mathrm{~mm}$ (Fig. 9). However, maximum rainfall intensity was slightly different, showing a maximum at $35.6 \mathrm{~mm} / \mathrm{h}$ for the accretionary sedimentary rock and a minimum at $18.4 \mathrm{~mm} / \mathrm{h}$ for the plutonic rock.

The particle size distribution of the suspended sediment and source materials collected from each source group is shown in Fig. 10. $D_{90}$, which is the sediment size that $90 \%$ of the suspended sediment is finer than, was $0.2 \mathrm{~mm}$ and $1.0 \mathrm{~mm}$, respectively, for sediment collected by surface water sampling and by the time-integrated suspended sediment sampler (SSS) at the outlet of the Nukabira River. All the potential source materials were significantly coarser than the suspended sediment, showing a difference in content of finer fractions of less than $0.2 \mathrm{~mm}$ among source groups.

\section{DISCUSSION}

The contribution of geological source areas seemed to be generally similar to the areal proportion of source groups defined by bedrock type within the Nukabira River watershed. However, disagreements were found in the accretionary basalt block and metamorphic rock areas, where the suspended sediment yields were the lowest and highest, respectively (Figs. 5 and 6). Compared to the distributions of slope failure and landslide scars, the highest sediment yield in the metamorphic rock may be attributable to the highest densities in slope failure and landslide scars (Fig. 8). In the accretionary basalt block, a high suspended sediment yield can be expected from the high densities in slope failure and landslide scars (Fig. 8), but it was the lowest among the source areas. In the plutonic rock, with the second highest suspended sediment yield, the density of slope failure was high, but landslide scars were not observed. These results suggest that in the case of a watershed with complex geology, the suspended sediment may not be simply explained by the distribution of slope failure and landslides.

Generally, suspended sediment provided from the hillslope to the channel, unlike sediment produced by slope failure, can be transported by surface erosion of the bare slope and bank erosion of the foot slope into the channel [Aipassa et al., 1990; Araya and Kuroki, 2001]. Aipassa et al. [1991] observed soil creep from active landslides in the midstream of Saru River (the geology appears to be serpentinite, although the literature found it to be sedimentary rock) and reported that the foot slope of the landslide continued to slide 1-2 m downslope to the channel. They concluded that the landslide was a major source of suspended sediment. Araya and Kuroki [2001] reported that the amount of sediment provided by surface erosion from landslide scars to the channel was 2 to 3 times larger than that from slope failure scars. Therefore, the result of this study - that the suspended sediment yield in the metamorphic area was the highest-can be supported by the dense landslide distribution in that area.

On the other hand, in the case of the accretionary basalt block, the lowest suspended sediment yield can be explained by the slaking and weathering features of the debris. Murakami et al. [2008] conducted a slaking test for bed rock materials and elucidated that in case of Neocene sedimentary rock, $99.7 \%$ of the original particles were slaked into finer particles, while in the case of accretionary basalt block, only $9 \%$ of original particles were slaked. Due to the resistance of the bed rock to weathering, the sediment transported from the hillslope to the river channel may have been deposited on the river bed and footslope as relatively large particles [Murakami et al., 2008], resulting in a low contribution to suspended sediment.

The second highest suspended sediment yield, shown by the plutonic rock, may be affected by the topographic features and particle size composition of the source material. The plutonic rock area was characterized by the fact that it had almost the highest altitude, slope gradient, and relief among the source groups (Fig. 7, Table 4). These steep topographic features can be expected to transport much more sediment [Tanaka and Ishigai, 1951; Ezaki, 1966; Mizutani, 1981; Marutani et al., 2000; Okano et al., 2004; Hasegawa et al., 2005]. Furthermore, the source materials collected in this 
study contain a high proportion of fine particles (Fig. 10), perhaps because granite, the dominant rock type of plutonic rock, is generally susceptible to weathering. These steep topographic features and fine particles available for transport most likely lead to a high sediment delivery ratio for the plutonic rock.

\section{CONCLUSION}

Suspended sediment sources estimated by a fingerprinting technique using natural radionuclides suggested differences in suspended sediment yield depending on the underlying bed rock type. The high suspended sediment yield in areas underlain by metamorphic rock can be attributed to dense landslides and slope failure scars, which are likely to continue to provide suspended sediment from the hillslope to the river channel by creeping soil during rainfall events. This result was supported by the hysteresis in suspended sediment concentration during the event [Abe et al., in this issue; Williams, 1989], showing higher suspended sediment concentration in the recession stage than in the increasing stage of runoff discharge. In the area underlain by plutonic rock, which also had a high sediment yield, fine sediment produced by weathering may be transported easily to the stream channel from the hillslope and/or footslope due to the steep topography. These areas with high suspended sediment yield may be characterized by geological and topographical features, with parameters suggested by the literature, such as creep, weathering, and slope gradient. In the area of accretionary basalt block, however, the low suspended sediment yield could be explained by neither the spatial density of landslides nor slope failure, but by the resistance to rock weathering. These results indicate that a comprehensive technique of hydrological monitoring and fingerprinting can provide a qualitative evaluation of suspended sediment yield from individual sediment sources on the basis of bed rock type in a catchment, although the reliability of fingerprinting using only three natural radionuclides still remains uncertain. Further studies are needed to improve the robustness of the fingerprinting technique, for example, by using other tracers as mineralogic and/or geochemical parameters complementarily.

ACKNOWLEDGMENT: The authors are grateful for the data and suggestions provided by the Muroran Branch of Hokkaido Development Bureau, Ministry of Land, Infrastructure, Transport and Tourism. The authors are also grateful for the field assistance provided by FUKUDA Hydrologic Center Co. LTD and Hokkaisuiko Consultant Corporation.

\section{REFERENCES}

Abe, T., Mizugaki, S., Toyabe, T., Maruyama, M., Murakami, Y. and Ishiya, T. (in this issue): High range turbidity monitoring in the $\mathrm{Mu}$ and Saru River basins: All-year monitoring of hydrology and sediment transport in 2010, International Journal of Erosion Control Engineering.

Aipassa, M. I. (1991): Landslide debris movement and its effects on slope and river channel in mountainous watershed, Research bulletins of the college experiment forests Hokkaido University, Vol. 48, pp. 375-418.

Aipassa, M., Shimizu, O. and Araya, T. (1990): Successive landslides and debris movement in forested drainage basin, Research bulletins of the college experiment forests Hokkaido University, Vol. 47, pp. 299-320.

Araya, T. and Kuroki, M. (Eds) (2001): Recognition and its methods for watershed dynamics, Hokkaido University Press, Sapporo, pp. 114-133.

Collins, A. L., Walling, D. E. and Leeks, G. J. L. (1997): Sediment sources in the Upper Severn catchment: A fingerprinting approach, Hydrology and Earth System Sciences, Vol. 1, pp. 509-521.

Collins, A. L., Walling, D. E. and Leeks, G. J. L. (1998): Use of composite fingerprints to determine the provenance of the contemporary suspended sediment load transported by rivers, Earth Surface Processes and Landforms, Vol. 23, pp. $31-52$.

Dai, F. C. and Lee, C. F. (2002): Landslide characteristics and slope instability modeling using GIS, Lantau Island, Hong Kong, Geomorphology, Vol. 42, pp. 213-228.

Ezaki, K. (1966): Study on sediment deposition in reservoir, Reports for Public Works Research Institute, Vol. 129, No.2, pp. 1-29 (in Japanese).

Foster, I. D. L. and Lees, J. A. (1999): Changing headwater suspended sediment yields in the LOIS catchments over the last century: A paleolimnological approach, Hydrological Processes, Vol. 13, pp. 1137-1153.

Fukuyama, T., Onda, Y., Gomi, T., Yamamoto, K., Kondo, N., Miyata, S., Kosugi, K., Mizugaki, S. and Tsubonuma, N. (2010): Quantifying the impact of forest management practice on the runoff the surface-derived suspended sediment using fallout radionuclides, Hydrological Processes, Vol. 24, pp. 596-607.

Furukawa, M. (1993): Natural radiation level in Japan Islands, Journal of Geography, Vol. 102, No. 7, pp. 868-877 (in Japanese with English abstract).

Geological Survey of Japan, AIST (Ed) (2009): Seamless digital geological map of Japan 1: 200,000. Mar30, 2009 version, Geological Survey of Japan, National Institute of Advanced Industrial Science and Technology.

Hasegawa, K., Wakamatsu, K. and Matsuoka, M. (2005): Mapping of potential erosion-rate evaluated from reservoir sedimentation in Japan, Journal of Japan Society for Natural Disaster Science, Vol. 24, No. 3, pp. 287-301 (in Japanese with English abstract).

Ishida, T., Nakayama, K., Okada, T., Maruya, Y., Onishi, K. and Omori, M. (2010): Suspended sediment transport in a river basin estimated by chemical composition analysis, Hydrological Research Letters, Vol. 4, pp. 55-59.

Joshi, S. R. (1987): Nondestructive determination of lead-210 and radium-226 in sediments by direct photon analysis, Journal of Radioanalytical and Nuclear Chemistry, Articles, 
Vol. 116, No. 1, pp. 169-182.

Kato, H., Onda, Y., Hiramatsu, S., Kashiwagi, S. and Miyamoto, K. (2005): Determining the sources of sediment using radionuclides in Nagasawa Reservoir catchment, upper Yoshino River, Journal of Japan Society of Erosion Control Engineering, Vol. 58, No. 2, pp. 5-14.

Koi, T., Hotta, N., Ishigaki, I., Matsuzaki, N., Uchiyama, Y. and Suzuki, M. (2008): Prolonged impact of earthquake-induced landslides on sediment yield in a mountain watershed: The Tanzawa region, Japan, Geomorphology, Vol. 101, pp. 692-702.

Marutani, T., Kasai, M. and Makita, M. (2000): Sediment volume yielded from small mountainous catchments eroded by landslides, Journal of Japan Society of Erosion Control Engineering, Vol. 52, No. 6., pp. 24-31 (in Japanese with English abstract).

Matsuda, H. and Minato, S. (1999): Radioactivity associated with rock in Japan, Radioisotopes, Vol. 48, pp. $760-769$ (in Japanese).

Mizugaki, S., Onda, Y., Fukuyama, T., Koga, S., Asai, H. and Hiramatsu, S. (2008): Estimation of suspended sediment sources using Cs-137 and $\mathrm{Pb}-210(\mathrm{ex})$ in unmanaged Japanese cypress plantation watersheds in southern Japan, Hydrological Processes, Vol. 22, pp. 4519-4531. Mizutani, T. (1981): Drainage basin characteristics affecting sediment yield from steep mountain basin, Journal of Japan Society of Erosion Control Engineering, Vol. 33, No. 4, pp. 1-9 (in Japanese with English abstract).

Mizutani, T. (2004): Estimation of the amount of sediment discharge from steep mountain basins using sedimentation data in sabo-dams, Journal of Japan Society of Erosion Control Engineering, Vol. 56, No. 5, pp. 27-32 (in Japanese with English abstract).

Murakami, Y. and Nakatsugawa, M. (2004): Slope failure, sediment yield and woody debris yield, In Report of research group for disasters occurred due to the heavy storm of typhoon No.10 in 2003 (Ed. Committee on Hydroscience and Hydraulic Engineering, Japan Society of Civil Engineering), pp. 46-56 (in Japanese).

Murakami, Y. and Watanabe, Y. (2007): Interpreting slope failure scars and estimation of sediment and woody debris budgets, Proceedings of the workshop on management of riparian forest and woody debris, Civil Engineering Research Institute for Cold Region, PWRI, Sapporo, July 31, 2007.

Murakami, Y., Yamashita, S. and Akaiwa, T. (2006): Grid based analysis of slope failure and estimation of sediment and woody debris yield on Saru River basin, Proceedings of the 3rd symposium on sediment disasters, pp. 75-80 (in Japanese with English abstract).

Murakami, Y., Suzuki, Y., Ikeshima, T. (2008): Studies on the micro-topography and sediment yield characteristics of the Saru River basin using airborne laser altimetry, Advances in River Engineering, Vol. 14, pp. 127-132 (in Japanese with English abstract).

Murray, A. S., Marten, R., Johnston, A. and Martin, P. (1987): Analysis for naturally occurring radionuclides at environmental concentrations by gamma spectrometry, Journal of Radioanalytical and Nuclear Chemistry, Articles, Vol. 115, No. 2, pp. 263-288.
Nishida, K., Kobashi, S. and Mizuyama, T. (1997): DTM-based topographical analysis of landslides caused by an earthquake, Journal of Japan Society of Erosion Control Engineering, Vol. 49, No. 6, pp. 9-16 (in Japanese with English abstract).

Ohishi, S., Sunada, K., Sisinggih, D. and Miyazawa, N. (2010): Study on estimation of sediment source by using mineral composition in Fuji river basin, Proceedings of Hydraulic Engineering, Vol. 54, pp. 673-678 (in Japanese with English abstract).

Okano, M., Takayanagi, J., Fujii, T. and Ando, A. (2004): Study of reservoir sedimentation management based on actual sediment inflow: The case of development of the sediment yield potential map, Journal of Japans Society of Dam Engineers, Vol. 14, No. 3, pp. 167-176 (in Japanese with English abstract).

Olley, J. M., Murray, A. S., Mackenzie, D. H. and Edwards, K. (1993): Identifying sediment sources in a gullied catchment using natural and anthropogenic radioactivity, Water Resources Research, Vol. 29, pp. 1037-1043.

Page, M., Reid, L. M. and Lynn, I. H. (1999): Sediment production from Cyclone Bola landslides, Waipaoa catchment, Journal of Hydrology New Zealand, Vol. 38, pp. 289-308.

Phillips, J. M., Russell, M. A., Walling, D. E. (2000): Time-integrated sampling of fluvial suspended sediment: A simple methodology for small catchments, Hydrological Processes, Vol. 14, pp. 2589-2602.

Tanaka, H. and Ishigai, H. (1951): On the relation of sedimentation of reservoirs to configuration and nature of rocks of catchment area (1st report), Journal of Japan Society of Civil Engineering, Vol. 36, pp. 173-177 (in Japanese with English abstract).

Uchida, T., Takahashi, F., Onda, Y., Sisinggih, D., Kato, H., Noro, T. and Osanai, N. (2009): Estimating soil erosion rate and sediment sources using radionuclide $\mathrm{Pb}$-210ex in upper Brantas river basin in Indonesia, Journal of Japan Society of Hydrology and Water Resources, Vol. 22, pp. 188-197 (in Japanese with English abstract).

Walling, D. E. (2005): Tracing suspended sediment sources in catchments and river systems, Science of the Total Environment, Vol. 344, pp. 159-184.

Walling, D. E., Owens, P. N. and Leeks, G. J. L. (1999): Fingerprinting suspended sediment sources in the catchment of the River Ouse, Yorkshire, UK, Hydrological Processes, Vol. 13, pp. 955-975.

Williams, G. P. (1989): Sediment concentration versus water discharge during single hydrologic events in rivers, Journal of Hydrology, Vol. 111, pp. 89-106.

Wollenberg, H. A. and Smith, A. R. (1990): A geochemical assessment of terrestrial gamma-ray absorbed dose rates, Health Physics, Vol. 58, pp. 183-189.

Yamagishi, H. (Ed) (1993): Landslide scars in Hokkaido: Distribution and description, Hokkaido University Press, Sapporo, pp. 392 (in Japanese).

Yeager, K. M., Santschi, P. H., Phillips, J. D. and Herbert, B. E. (2002): Sources of alluvium in a coastal plain stream based on radionuclide signatures from the ${ }^{238} \mathrm{U}$ and ${ }^{232} \mathrm{Th}$ decay series, Water Resources Research, Vol. 38, pp. 1242. 